\title{
ERRATUM
}

\section{Effectiveness of Intraindividual Variability in Detecting Subtle Cognitive Performance Deficits in Breast Cancer Patients - Erratum}

Barbara Collins, Gerard Widmann, AND Giorgio A. Tasca

doi: 10.1017/S1355617718000309. Published online by Cambridge University Press on 8 June 2018.

The paper by Collins et al. (2018) contains an error on page 724 that should be brought to the attention of readers. It is listed here, along with the incorrect and correct copy:

Incorrect copy: Received October 24, 2017; Final Revision March 8, 2018; Accepted March 27, 2018; First Published Online June 8, 2018

Correct copy: Received October 24, 2017; Final Revision March 8, 2018; Accepted March 28, 2018; First Published Online June 8, 2018

Cambridge University Press regrets the inconvenience that this error may have caused. The article has been updated with the correct copy. 